\title{
Religion, violence and abuse
}

\begin{tabular}{|c|c|}
\hline \multicolumn{2}{|c|}{$\begin{array}{l}\text { Author: } \\
\text { Maake J. Masango }{ }^{1}\end{array}$} \\
\hline \multicolumn{2}{|c|}{ 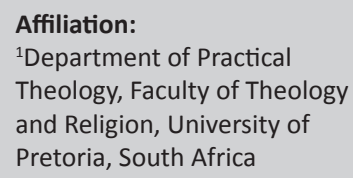 } \\
\hline \multicolumn{2}{|c|}{$\begin{array}{l}\text { Research Project } \\
\text { Registration: } \\
\text { Project Leader: M.J.S. } \\
\text { Masango }\end{array}$} \\
\hline \multicolumn{2}{|c|}{ Project Number: 02467526} \\
\hline \multicolumn{2}{|c|}{$\begin{array}{l}\text { Description: } \\
\text { This research is part of the } \\
\text { project, 'Pastoral Care and } \\
\text { Trauma Counselling', directed } \\
\text { by Prof. Dr Maake Masango, } \\
\text { Department of Practical } \\
\text { Theology, Faculty of } \\
\text { Theology, University of } \\
\text { Pretoria. }\end{array}$} \\
\hline \multicolumn{2}{|c|}{$\begin{array}{l}\text { Corresponding author: } \\
\text { Maake Masango, } \\
\text { maake.masango@up.ac.za }\end{array}$} \\
\hline \multicolumn{2}{|c|}{$\begin{array}{l}\text { Received: } 08 \text { June } 2018 \\
\text { Accepted: } 20 \text { Aug. } 2018 \\
\text { Published: } 06 \text { Dec. } 2018\end{array}$} \\
\hline \multicolumn{2}{|c|}{$\begin{array}{l}\text { How to cite this article: } \\
\text { Masango, M.J., 2018, } \\
\text { 'Religion, violence and } \\
\text { abuse', HTS Teologiese } \\
\text { Studies/Theological Studies } \\
\text { 74(3), a5144. https://doi. } \\
\text { org/10.4102/hts.v74i3.5144 }\end{array}$} \\
\hline \multicolumn{2}{|c|}{$\begin{array}{l}\text { Copyright: } \\
\text { (c) 2018. The Authors. } \\
\text { Licensee: AOSIS. This work } \\
\text { is licensed under the } \\
\text { Creative Commons } \\
\text { Attribution License. }\end{array}$} \\
\hline \multicolumn{2}{|c|}{ Read online: } \\
\hline 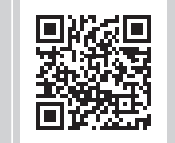 & $\begin{array}{l}\text { Scan this QR } \\
\text { code with your } \\
\text { smart phone or } \\
\text { mobile device } \\
\text { to read online. }\end{array}$ \\
\hline
\end{tabular}

Abrahamic faith-based religions are always regarded as peaceful. The question to ask is as follows: how do its followers use violent text in order to justify their action? This article analyses how extremists within these faiths abuse the text and use violence as a means of forcing non-believers into their faith. They claim that God often sanctions their actions of violence.

\section{Introduction}

There is far more violence in the Bible than in the Qur'an. Therefore, the Western world promoted the idea of Islam being a violent religion. Some scholars (Armstrong 1993) also raised the issue of the crusades as a great example of violence in scriptures. Bistrich (2007) explains the above idea in detail: he says:

There is far more violence in the Bible than in the Qur'an; the idea that Islam imposed itself by the sword is a Western fiction, fabricated during the time of the crusades when, in fact, it was Western Christians who were fighting brutal holy wars against Islam. (pp. 19-21)

This quote sums up the single most influential argument currently serving to deflect the accusation that Islam is inherently violent and intolerant: All monotheistic religions, proponents of such an argument say, and not just Islam, have their fair share of violent and intolerant scriptures, as well as bloody histories. Thus, whenever Islam's sacred scriptures - the Qur'an first, followed by the reports on the words and deeds of Muhammad (the Hadith) - are highlighted as demonstrating the religion's innate bellicosity, the immediate rejoinder is that other scriptures, specifically those of Judeo-Christianity, are as riddled with violent passages. The whole idea is that this quotation sums up some of the most influential arguments currently being debated by the above scholars.

Serving to deflect the accusation that Islam is inherently violent and intolerant, Nardin (1996), Safi L.M. and other scholars in their research reveal that all monotheistic religions, and not just Islam, have their fair share of violent and intolerant scriptures, as well as bloody histories.

I am aware that Islam's sacred scripture - the Qur'an - first followed by the reports on the words and deeds of Muhammad (the Hadith) is highlighted as demonstrative of the religion's innate bellicosity. The immediate rejoinder is that other scriptures, specifically those of Judeo-Christianity, are as riddled with violent passages, for example, Psalm says: 'Happy shall he be who takes your little ones and dashes them against the rock' (Ps 137:9). Members of the community sometimes confuse the issue of terror with Islamic faith. This is the reason why they regard or customarily paint Islam as a violent religion because of some terrorist activities acted out by some of the radical Muslim groups.

Armstrong was right when she included violence demonstrated in the Bible. She says (quoted also by Bistrich): 'There is far more violence in the Bible than in the Qur'an' (Armstrong 2005a: 18-20). She further says: 'the idea of violence in this faith is raised more by western fiction and videos that are promoting one sided story of violence' (2007:23). In other words, all religions have their fair share of violent and intolerant scriptures, as well as bloody histories. It is important for the reader to note that most, if not all, monotheistic religions acknowledge that their religion justifies violence. These concepts finally contain the seeds of violence. It is also important to note that the crusades were violent and led by atrocities of the modern world's standards under the banner of the cross, and in the name of God (Christianity); my own opinion is that the crusades were a counterattack on Islam. History taught us that the invasions and atrocities against Christians were on the rise in the decades before the launch of the crusades in 1096. The reader needs to understand that it was the grievances and frustrations of the Muslims, which were ever exacerbated by economic, political and social factors, that made them react through violent means. Today wars are waged because of greed and materialism among the 
developed and the so-called undeveloped countries. This leads powerful countries to justify violence. Western world leaders keep asking the same question as to why Islam is violent. Now the time has come that we also ask the same question to Judaism and Christianity. All faiths have used violence in relation to others.

A good example is found in the use of a theological justification of violence, based on the biblical perspective of apartheid. This issue created hatred, violence and abuse among South Africans, to the extent that violence, protected by law, was used in order to oppress others. When the black people responded by using violence, they also responded by the same means saying it is essential to keep law and order.

In other words, we are talking about the theology of hate, anger and revenge, which caused black people to react violently to systems of oppression in order to defeat those who had violently offended them, through systems of oppression. I am aware that colonialism had its own system of violence, but I want to focus on violence centred on apartheid. This system began breathing a kind of cycle of violence, which could be justified by theology, especially among South Africans. The worse part of this journey was when the Church and its theologians supported this process.

The very building we are meeting in was a place where the craft of theological oppression was manufactured and justified, and it became the norm of truth and finally a way of living the truth of oppression. ${ }^{1}$ In short, a white supremacy policy of apartheid was formulated in the name of Christianity.

This system created some of the violence we are experiencing in South Africa. We (inter-religious faith-based organisations) all have our dark passages of violence against others, using our faith (which seeks to share light to others, or the so-called gentiles, that is, people who do not believe). In this way, we are able to justify our acts of violence in the name of God. It is not surprising that many of the key leaders (during apartheid times) began interpreting this philosophy biblically and helped people live it out in their own lives.

Their constituency, in order to support this theology, was allowed to use violence against those who were against this kind of philosophy, in the name of God and religion. The response to the above theology, or philosophy, by the black community was an important Kairos document in 1985, which sought to address this issue that violated human rights, irrespective of colour and their religion. The main question they faced was the following: 'can the Bible be used for any purpose at all?' Looking back at this journey of oppression, the answer is 'yes'. Note that this is not unique to the Bible, as all other holy religious texts had used the same violent tactics of interpretation to justify violence.

1.The conference was held at the University of Pretoria, where some of the old theologians created that system of apartheid, and even supported it.
Islam, on the other hand, could not escape from justifying violence through the Qur'an 9:5. ${ }^{2}$ It mandates that idolaters and polytheists either must convert to Islam or be killed, simultaneously. Another example is based on 9:29, which is the primary source of well-known discriminatory practices against conquered Christians and Jews living under Islamic suzerainty. Jenkins (2009) cites some of the people who lived through experiences of violence. They respond by quoting the Torah, the Jewish scripture, which permitted people to retaliate an 'eye for an eye, tooth for a tooth, a hand for a hand, a foot for a foot' (Ex 21:24), but like the gospel the Qur'an suggests that it is meritorious to forgo revenge in a spirit of a charitable benevolence (Surah 5:45). In other words, hostility must be brought to an end as the enemy pleads for peace. Khalid, a law professor from US, has provided a good response that will help shed light on the above issue. He says: 'The meaning of the text is often only as moral as its reader'. He continues to say that: 'if the reader is tolerant, hateful or oppressive, so will be the interpretation of the text' (Khalid Abou El Fadl 2002) (Retrieved 21 August 2017).

Let me share an example of how we (and the reader) can prejudice this text. The reader could miss the oft quoted 'Kill them whenever you find them' (Surah 1:1). Reading the text, one can misinterpret this by ignoring the text mentioned before 'Kill them' which says: 'In the name of God, The beneficent, and the merciful'. Once the text is out in public, it depends on the reader and his or her interpretation. The above text could be justified as a reason to kill others who are not in the same religion. This is where 'Muslim Terrorist' contradicts Islamic ideals of religious tolerance. The point I am making is that most of our religions have some violence text, which must be carefully read, or understood. We need to read the texts of Islam and Christianity carefully, especially where they grant permission to fight in war, that is, when attacked by others.

\section{Violence among human beings}

The issue of violence and abuse has become our daily bread in South Africa, and globally, because of some political leaders. Some of them will use religion in order to misgovern their people. As mentioned before, the word 'terrorism' makes us (9/11, Boko haram, etc.) to associate violence with the Islamic religion. We also connect it with emotions in such a way that we lose the perspective as well as the motive behind the attack. We forget the action that caused them to react with a violent act when they are struggling with injustices, oppression, and frustrations that affect their daily lives.

The attack of $9 / 11$ on US soil, and a year later the Bush administration's enduring war on terrorism in Afghanistan and Iraq, has all served to reinforce the widespread violence and its attachment to Islam as a violent religion. Reaction from the Middle East, and some Islamic countries responding with violence, caused some to use suicide bombs in order to take revenge against the enemy. With regard to the topic of 2.All translations of Qur'anic verses are drawn from Arberry (1996) 
religion-related violence that has become a part of our lives globally, we need to mention that in most of our religions there are extremists and fundamentalists who will go beyond the call of duty and then justify violence in the name of religion. This does not qualify to say that all are violent because of the actions of a few extremists.

Pallmeyer articulates this kind of religious violence by saying: 'Human violence is inevitable as long as those of us, who are practitioners of competing religious faith, give legitimacy to violence-of-God traditions' (2003:XVI). This statement concludes by saying that human beings (religious ones in particular) become violent in order to defend their religious beliefs.

Let us remember how the Crusaders responded in violent ways because of how they were treated by Muslims, as mentioned before. This led them to react violently through atrocities, by modern world standards, under the banner of the cross, and in the name of Christianity and the God they worshipped. They justified their violence by waging violent holy wars against Muslims. However, we also need to note that the Crusades were a counterattack on Islam. Muslim invasions and atrocities against Christians were on the rise in the decades before the launch of the Crusades in 1096. In other words, we also need to take note of events that lead to violence in the name of their religion. The readers will now understand why this becomes a stereotypical way of labelling religion as fuelling violence among human beings, and purporting that those who are hurt are the innocent ones (women and children).

Debriatz actually adds onto this idea by saying, 'The act of violence begins when others demonise the other as an enemy' (2000:293). He further develops or continues his thoughts demonising others by saying that: 'satanization of the enemy, putting the enemy on the cosmic plane where they are unholy and therefore subhuman' (Debriat 2000:294).

This is a classic case that religious people use in order to justify labelling others as the 'anti-Christ' etc., or 'antireligion'. Therefore, we can eliminate them in the name of our God. It is interesting to note that where religion or faithbased organisations are present, violence seems to follow. Going by the examples of Somalia, Sudan, Rwanda, etc., one will understand why Crusaders used this method in order to destroy those who were against them. One of their focuses or roles of their religion was provoking violence and facilitating its practices against the enemy. In the case of the Aryan conflict, they were seen as 'God's people' while Jews were the 'descendants of the devil'. One could see how the root of demonisation (in this case) stems from Jewish people, and it is used as a tool to create the enemy, and demonise them in order to justify ethnic and religious violence.

Finally, this leads to the death of people due to religious violence, which justifies their actions against the enemy.
Who among us can say that extremists in our faith-based organisations use their religion in order to justify violence? At times, the followers use rituals in order to strengthen their use of violence, especially among those who are against others.

In view of the above statement, let us now analyse how rituals have become a part of violence and are used to violate non-believers in religion. Gluckman says, 'They are set apart as a body of customs specifically associated with religious performance' (1962:20-24). To him a ritual is clearly not a fact of nature but a concept, and definitions of concept should, therefore, be operational and the merits of any particular formula will depend on how the concept is being used. With the above in mind, let us analyse how various religions used this concept, especially in promoting violence.

\section{Rituals add to violence in religions}

Mbiti has a beautiful way of introducing rituals in his writings. He says, 'To be human is to belong to the whole community, and to do so involves participating in the beliefs, ceremonies, rituals and festivals of the community' (Mbiti 1999:3). With this quotation, let us now analyse the issue of rituals.

Ritual is arguably a universal feature of human social existence; just as one cannot envision a society without language or exchange, one would be equally hard pressed to imagine a society without ritual. The word ritual brings to mind eroticised images of primitive others diligently engaged in mystical activities; one could find rituals, both sacred and secular, throughout 'modern' society. A clear example can be seen by collective experience, from the Olympics to the commemoration of national tragedies, cyclical gathering, from weekly congregational gathering, thanksgiving in the US, Mardi Gras, etc. In short, ritual is, in fact, an inevitable component of culture, extending from the largest-scale social and political process to the most intimate aspects of our selfexperience. It is important for the reader to note that there are good and bad elements in rituals. This article focuses on violent rituals that are used in oppressing and abusing others.

Some of the religious rituals provoke violence among believers. Jenkins (2009) suggests that:

The function of rituals is to inspire the seeker to bring order in a context dominated by chaos, to create collective certainty in times of ambiguity, to create new meaning, to redefine or to dismantle an extinct intimation in a spiritually controlled ambiance. (pp. 12-14)

In other words, people need meaning in order to survive in life. Armstrong also develops these ideas by saying: 'We are meaning-seeking creatures and, unlike animals, fall very easily into despair if we fail to make sense of the issues facing us - then we enforce them on others' (Armstrong 2005b:6). No wonder we fall prey when entering into violence in order to protect that which we believe in, because our rituals create sacredness, which we will justify and even protect through 
violent means. These kinds of rituals, when followed deeply through religious practices, create a space which breeds violence. Girard was right when he said: 'religion is a phenomenon of trust and stability' (1979:46), while in its institutionalised form it becomes a source of peace or violence, as mandated by interest (Goldstone 2001:50)

My own conclusion from the above reasoning is that, when religion is taken seriously, without justice issues, it promotes violence among human beings. Its rituals become violence and finally express its violent acts through the rituals of bloody and bloodless sacrifice. This process will lead religion to display the deadly fury of rivals expressed through violent means. It will finally lead to scapegoating others (demonising), as a means of expressing violence, especially against those who are opposing its rituals. Today, we are able to analyse some of those religious practices that involve violence. As mentioned before, that all religions are violent, no one can claim non-violence in his or her religion. Let me share a few of the faith groups that use rituals in a violent way.

\section{Hinduism}

In this religion, violence developed during the Brahmanic period (BC 1000 through AD 400) clearly seen through venues of Dharma and Yoga. Dharma involves animal sacrifice, and it is imposed on social conformity in a discriminatory and violent fashion. Oldenburg explained ritual killings in the following way, during these times: he says: "The Vedas imposed the killing of an animal in order to free oneself from the sin of bloody deeds, and from impending revenge' (Oldenburg 1988). Hinduism deals with rituals as a way of cleansing themselves from violent act in this one way.

In other words, the whole process is anchored in the tradition of the ascetic (tapasvin); yoga interiorised the Vedic sacrifice within the concept of mental liberation, through meditation and non-violence. Nayak (2000) clarifies some of these aspects by asking this question:

If the path of dharma offered detailed rituals of violence, then the path of yoga developed specific mental techniques to destroy violence from its roots that are found in the human heart. (pp. 66-67)

It is important to note how adherents of this religious group dealt with the concept of violence in their faith.

\section{Buddhism}

At the recent cultural event on peace in Sri Lanka, Gregg demonstrates reality in the following way: 'Reality defies the popular perception of Buddhist as a religion of peace' (Gregg 2014:74-75). Nayak says that the goal of a monk is to attain enlightenment and become a bodhisattva: which simply means a saint who deeply embodies the quality of non-violence (Nayak 2000:176). Through reading of the concept of Buddhism and monks I also agree with the above understanding of the goal of monks. This idea leads to meditation, which becomes important to monks, as it leads them to peace and non-violence. Hence, a ceremonial reading is practiced twice a month, so that 'Hate must be overcome by the absence of anger: evil must be overcome by good: greed must be overcome by liberality: lies by truth' (Ferguson 1978:46).

Once again, we see the struggle with violence among believers being changed in order to focus on peace. At times, they face negative elements in life. There are instances in which Buddhism considers ritual killing to be a path towards enlightenment and towards attaining instantly the status of bodhisattva. They are forced to deal with violence as a ritual of cleansing. For example, in AD 515, a Chinese ruler Fa-Ch'ing led an army of 50000 rebels and announced that any of his troops who killed an enemy would become a bodhisattva on the spot (Ferguson 1978:52). Justification of violence through rituals becomes important. It is important to note how followers dealt with these issues of violence.

\section{Justification of killing}

Mahayana Buddhists, who identified five circumstances in which killing was justified and commended as a ritual act, share the above idea or concept, by quoting Mahaparinirvana Sutra (cited by Ferguson 1978):

1. 'Who Claims that in a previous life, Buddha killed a Brahman in order to protect the accuracy of the doctrine.

2. Buddha Killed a bandit plotting to assassinate and rob 500 merchants - thus saving 500 lives at the expense of one - at the end everyone was spiritually saved. In other stories, the killer monk is the Buddha himself.

3. If Buddha taught that everything is an illusion, then killing does not exist because there is no soul or self; therefore nothing to kill.

4. Asanga, Buddhist monk recommends that it is better to kill than to be killed.

5. As everything is predestined, the act of killing must be part of one's destiny, and as such, it becomes permissible to kill'. (pp. 55-56)

The reader can now clearly understand how monks will justify the killing of another person, through performing some of the above acts. On the other hand, rituals that permit them to deal with violent acts aimed towards them. In other words, the concept of enemy is developed, and demonisation becomes part of the ritual of killing a non-entity.

\section{Judaism}

This Abrahamic faith often connects or combines the act of worship with a holy war. Instruction or prayer is used as an integral part of the rituals to evoke God to be on the side of their military or righteous Jews. Some of the anecdotes from the Bible as well as from Judeo-Christian history illustrate what Jenkins points out; two good examples are in Christianity, which are regularly mentioned by feminist scholars, such as Fiorenza (1987) and Trible (1984). The military conquest of the land of Canaan by Hebrews, in 1200 BCE, is often characterised as 'genocide', and has all 
but become a visible symbol of biblical violence and intolerance. God said to Moses:

But of the cities of these people which the Lord your God gives you as an inheritance, you shall let nothing that breathes remain alive, but you shall utterly destroy them ... etc. (Dt 20:16, 18)

The second one is cited in Joshua:

Conquered all the land, the mountain country and the South and the lowland and the wilderness slopes, and all their kings; he left none remaining, but utterly destroyed all that breathed, as the Lord God of Israel had commanded. (Jos 10:40)

Once again, we are introduced to the concept of the enemy who has no self. As a result, we can do anything to the 'devil' who has no soul, in the sight of God. Hitler used (by Allan Hall for Mail Online Updated: 14:35 BST, 19 June 2009) this concept in order to justify the killing of the Jews (retrieved it on 07 August 2018). The readers need to know that the person who is anti-others and God is illuminated, and thus justify their own religious action to kill the other. With this concept in mind, let us look at the episode from Exodus, which is and was used by Judaism and Islam. In this story, Israel depended on Moses being able to raise his hands during the time of prayer:

As long as Moses held up his hands, the Israelites were winning, but, whenever he lowered his hands, the Amalekites were winning. When Moses' hands grew tired; they took a stone and put it under him and he sat on it. Aaron and Hur held his hands up - one on one side, one on the other - so that his hands remained steady until sunset. So that Joshua overcame the Amalekite army with the sword. (Ex 17:11-13)

\section{Response to rituals}

Violence-oriented rituals always invoke ritual killings of enemies, which includes animal sacrifice. This then becomes a worship, often performed and based on mythical battles against the enemy, says Eisen (2011). He further says that, in this case, it is against Israel's mortal enemies. Eisen elaborates on this issue (2011:25). Judaism also included nazarite rituals of separation based on Numbers 6:1-21. The people shall perform rituals while they have separated themselves from others. These are individual peace offerings taken before the holy alter. This ritual was followed by the ritual of purification, which involved abstinence from alcohol, not cutting hair, touching of a corpse, etc. This process connects closer to African theology. For example, during the time of mourning, Africans will follow the same patterns. During this time, the lamb or goat is used in this ritual, cleansing the tribe or family from misfortune. The practice is based on the ritual of Olah (i.e. the lamb as a burnt offering), the hatal (sheep as sin offering) and finally the Shelamim (ram as peace offering). Many independent Churches still worship in this way. One can understand the issue of Zionism, which involves violence currently. Let me conclude by sharing violence inspired from Zionism. Eisen writes, 'Judaism has inspired violence not just in religious Zionism, but in secular Zionism as well' (2011:145). This kind of violence was demonstrated by the killing of Israel's Prime Minister, Yatzhak Rabin by Yigar
Amir. Before the killing, Armir allegedly received the blessings of a rabbi who declared that he acted according to din rodef (i.e. the law of the pursuer) (Pendahzur \& Perliger 2009:106-107). In other words, they see his death (religiously) as part of sacrifice, for the sake of the nation.

When followers believe in such violent rituals against non-believers, they can do anything to the so-called enemy. A typical example is how Gentiles were treated in the Jewish faith. The military conquest of the land of Canaan by Jews in 1200 BCE is often characterised as a 'genocide' and has all but become emblematic of biblical violence and intolerance. For example, God told Moses: Verse 16:

But of the cities of these people (gentiles) which the Lord your God gives you as an inheritance, you shall let nothing that breathes remain alive. Verse 17 However, you shall destroy them-the Hittites, and the Amorites, the Canaanite, and the Perizzite, the Hivite, and the Jebusite. Just as the Lord your God has commanded you, Verse 18 lest they teach you to do according to all their abominations, which they have done for their gods, and you sin against the Lord your God. (Dt 20:16-18)

It is interesting to note that Joshua (Moses' successor) was able to conquer them and all their land. The mountain country and the South, and the lowland and the wilderness slopes, and all their kings; he left none remaining, but utterly destroyed all that breathed, as the Lord, God of Israel had commanded (Jos 10:40). When reading the above passage, my thoughts kept imagining the Rwandan genocide. It explained the dark days when human beings used war in order to teach others to respect their belief systems. This might have led them to justify violence by using scriptural texts. The danger is to invite God who directs them to eliminate the other. With the above thinking in mind, let us analyse rituals of Islam, especially when faced with war.

\section{Islam}

This is where Islamic violence is unique. Though similar to the violence of the Old Testament - commanded by God and manifested in history - certain aspects of Islamic violence and tolerance have become standardised in Islamic law and apply at all times. Thus, while the violence found in the Qur'an has a historical context, its ultimate significance is theological. Here is a classic case from Qur'anic verses, known as 'Sword-verses' Surah 9:5:

Then, when the sacred months are drawn away, slay the idolaters wherever you find them, and take them, and confine them, and lie in wait for them at every place of ambush. But if they repent, and perform the prayer, and pay the alms, then let them go their way. (Arberry 1996:68)

Rituals of violence are conducted prior and during military confrontation, mainly as an act of encouragement and as forms of spiritual discipline designed to ensure that the battle is conducted for the benefit of Islam. The ritual is directed externally to enemies, as well as internally, as a devotional symbol. 
Externally the shahada and Allah Akbar (Allah is the great one) are chanted. There is no God but Allah, and Muhammad is his prophet, is chanted in preparing the crowd for a violent confrontation. When the moment of confrontation is imminent, prophet Muhammad prescribes Allahu to each holy fighter to ensure spiritual legitimacy when fighting on the path of Allah Akbar. These are some of the rituals used in the past by Christians in order to justify violence, being especially against non-believers. The main question to ask is the following: why should Jews and Christians point to the Qur'an as evidence of Islam's violence while ignoring their own scriptures and history?

\section{Conclusion}

The research clearly shows that history and theology promote violence by conflicting the temporal actions of human beings, with what are understood to be the immutable words of God. The fundamental error is that of Judeo-Christian history, which is violent, and is being conflated with Islamic theology, which commands violence. Of course, the three major monotheistic religions have all had their share of violence and intolerance towards 'others'. Whether God ordains this violence or whether war-like men merely wished it thus is the key question.

Remember that all major monotheistic religions have all had their share of violence and intolerance towards the 'other'. I want to conclude by saying that all these kind of justifications of holy wars are offensive and unjust to humanity. This is one of the reasons that people abuse religion and manipulate it to suit their belief. For those who refuse to align themselves with their thinking, violence is used in order to force them to believe in their theological concept. I want to challenge the reader, by quoting from the New Testament, especially concerning what Christ expects from us.

As a Christian, I am aware that the above texts are not based on the example of Jesus, who said to his followers: 'Love your enemies, bless those who curse you, do well to those who hate you, and pray for those who spitefully use you and persecute you' (Mt 5:44).

I am also aware that it took centuries of theological debate, from scholars like Augustine to Aquinas, (Boniface 2012:64) to rationalise defensive war, articulated as 'just war', while human beings were dying in the name of what is called 'just' and Godly? For me, it is the Crusaders, not Jihadists, who have been less than faithful to their scriptures. We cannot tolerate violence, which affects women and children in our time, while men predispose or prescribe holy wars that are violent and call them just.

Is this how Christians are to behave, who are commanded by the Lord, to love, bless and act kindly towards their enemy with such reverence of goodness, we are ordered to love our enemies? If we fail to do so, how much more can be expected of Muslim believers, who, while sharing the same violent tendencies, are further commanded by Allah to attack, kill and plunder non-believers?

Let me conclude by saying, what gift do we have to give to the next generation. How can we model a non-violent and peaceful community to those who follow us?

\section{Acknowledgements Competing interests}

The author declares that he or she has no financial or personal relationships which may have inappropriately influenced him or her in writing this article.

\section{References}

Arberry, A.J., 1996, The Koran interpreted: A translation, Touchstone, New York.

Armstrong, K., 1993, Spiral staircase my climb out of darkness, Random House, New York.

Armstrong, K., 2005a, Jerusalem: One city, three faiths, Random House Ico, New York. Armstrong, K., 2005b, A short history of myth, Canongate, New York, NY.

Bistrich, A., 2007, Discovering the common grounds of world religions, an interview with Karen Armstrong, share international 19-22 September 2007, viewed 20 July 2018, from www.dissidentvoice.org

Boniface, R, 2012, The city of God, New City Press, New York.

Debriatz, B.A., 2000, The white separatist movement in the United States: White power, White Pride, The Johns Hopkins University Press, Minneapolis, MN.

Eisen, R., 2011, The peace and violence of Judaism: From the Bible to Modern Zion, Oxford University Press, Oxford.

El Fadl, K.A., 2002, Islam and the challenge of democracy, Princeton University Press, Princeton.

Ferguson, J., 1978, War and peace in the world of religions, Oxford University Press, Oxford.

Fiorenza, E.S., 1987, In memory of her: A feminist Theological reconstruction of Christian origins, The Cross Publishing Company, New York.

Girard, R., 1979, Violence and the sacred, transl. P. Gregory, The John Hopkins University Press, Baltimore, MD.

Gluckman, R., 1962, Less rites of passage, University Press, Manchester.

Goldstone J 2001, 'Towards a fourth generation of revolutionary theory', Annual Review of Political Science 4, 139-187. https://doi.org/10.1146/annurev. polisci.4.1.139

Gregg, H.S., 2014, The path of salvation, religious Violence from the Crusaders to Jihad, Potomac Books, Lincoln, NE.

Jenkins, P., 2009, Dark passages, The Boston Globe, New York.

Kairos Document, 1985, Challenges to Churches: A theological Commend on the political crisis in South Africa, Eerdmans Publishing Co, Grand Rapids, MI.

Mbiti, J.S., 1999, African religions and philosophy, Heinemann, A division of Reed Publishing USA Inc, Nairobi.

Nardin, L.E., 1996, The Islamic threat, myth or reality?, Oxford University Press, Oxford.

Nayak, T., 2000, In the ethics of war and peace: Religious and secular perspectives, Princeton University Press, Princeton.

Oldenburg, H., 1988, "'Religion of the Vedas", Motilal Banarisidas, Delhi, in V. Das "Violence and Nonviolence at the Heart of Hindu Ethics", in M. Juergensmeyer, M. Kitts \& M. Jerryson (eds.), The Oxford handbook of religion and violence, pp. 17-18, Oxford University Press, Oxford.

Pallmeyer, J.N., 2003, Religious killings vs violence in the Bible and the Qur'an, New York: Continuum, Trinity International, Harrisburg, PA.

Pendahzur, A. \& Perliger, A., 2009, Jewish territory in Israel, Columbia University Press, New York.

Trible, P., 1984, Texts of terror: Literary-feminist readings of Biblical narratives, Fortress Press Philadelphia, PA. 